\title{
Presence of native trees in rural tribal homegardens does not necessarily mean conservation: A case study from Mishmi belt of Arunachal Pradesh, India
}

\author{
Inda Mihu ${ }^{1}$, Dipankar Borah ${ }^{1,2, *}$, Sumpam Tangjang ${ }^{1, *}$ \\ ${ }^{1}$ Department of Botany, Rajiv Gandhi University, Rono Hills, Doimukh-791112, Arunachal Pradesh, India \\ ${ }^{2}$ Department of Botany, Goalpara College, Goalpara-783101, Assam, India \\ *corresponding authors email address: sumpam.tangjang@rgu.ac.in, dipankar.borah@rgu.ac.in
}

Received: 19 September 2021 / Accepted: 15 November 2021

\begin{abstract}
Increasing human population and various developmental activities in the Indian state of Arunachal Pradesh, which lies in one of the most bio-diverse regions of the world, has caused large-scale deforestation, pushing a large number of native tree species to the serious verge of elimination from their native forest. In such tribal-dominated landscapes around the world, myriads of studies have emphasized the potential of homegardens as a site for local biodiversity conservation as they are known to have a huge Indigenous Knowledge System (IKS) on the use of diverse native floras. The present study was, therefore, undertaken to investigate if the native communities of the Mishmi tribe conserved native indigenous tree species in their homegardens and if they are grown then what is the future of these tree species? It was hypothesized that harbouring greater indigenous knowledge implies greater domestication of tree species in their homegardens. Altogether, 103 species of trees were recorded from 243 homegardens in the present study. Although the native species constituted more than half of the species diversity, they, however, greatly lagged in all other aspects of the study such as population share, frequency distribution and regeneration potential. Native tree species constituted just $37 \%$ of the total tree population. Only two species, Bauhinia variegata L. and Alnus nepalensis D. Don, made up the major bulk of the native population. In terms of frequency distribution, only a handful of native species maintained a decent presence in the homegardens. Most of the native species grew naturally in unmanaged homegardens. The regeneration potential of all native species was very poor, including $B$. variegata. The study demonstrates that out of the 76 native species recorded from the region, only 7 species can rightfully be regarded as being domesticated by virtue of IKS of the Mishmi community. Our study concludes that the native species do exist in large number in homegardens of the rural tribal areas, but most of the native wild species exist in the rural homegardens not because they are planted/preferred but because they just happen to randomly grow there since most of the homegardens of tribal household are unmanaged or poorly managed, thereby giving way to wild species to germinate, at least until the owner decides to weed them out.
\end{abstract}

Keywords: homegardens, Himalayas, indigenous knowledge, tree diversity.

\section{Introduction}

In the face of increasing deforestation and forest loss around the world, biodiversity conservation has today become one of the major concerns of scientists and conservationists alike. Northeast India, being a part of the Indo-Burma biodiversity hotspot of the world, is one of the most biodiverse regions in the country, supporting nearly about
$50 \%$ of the biodiversity of India (Mao \& Hynniewta, 2000; Paul et al., 2005). Along with the nation, this region has also been witnessing increasing forest loss (Ramakrishnan, 1984; Gupta et al., 2005; Reddy et al., 2015). Arunachal Pradesh, inhabited by indigenous tribal folk, with 26 major tribes and more than 100 sub-tribes, is one the remotest states located in the northeastern Himalayan region of India. The state is home to many endemic, rare, and endangered species. The 
state has witnessed a sharp increase in human population in the last few decades (Census of India, 2011; Kanwal, 2014), and the relationship between population increase and forest depletion has been on work in the state too (Bhuyan et al., 2003; Lele \& Joshi, 2009; Ravindranath et al., 2012), especially due to expanding human settlement, agriculture and changing lifestyle of people in the region (Lele \& Joshi, 2009; Tangjang \& Nair, 2016; Tsering et al., 2019). In the face of such deforestation and species loss, many researchers have portrayed agroforestry land management practices such as homegardens as an important way of conserving biodiversity. Homegardens are especially important in the context of the rural areas and the regions inhabited by the tribal population where they play an important role in livelihood sustenance (Barbhuiya et al., 2016). Lots of recent studies have emphasized the importance of the IKS of various tribal communities around the world (especially those residing adjacent to the forests) as an important potential tool for biodiversity conservation, both in homegardens and the local forest, as the tribal communities around the world are known to harbour huge IKS on the use of various floras in the forest (Gadgil, 1987; Gadgil et al., 1993; Berkes, 2000; Das \& Das, 2005; Parrotta \& Agnoletti, 2007; Galluzi et al., 2010; Fraser et al., 2010; Kumar \& Tiwari, 2017; Idohou et al., 2014; Yang et al., 2018). They have been known to domesticate many wild species of the floras in their homegardens and other agroforestry lands as a part of their livelihood security and cultural practices. This agroforestry land practice can be the only place where some of the native tree species now survive outside the natural forest. Like any tribal communities around the world, the tribal population in Arunachal Pradesh have also been known to collect diverse local tree products from adjoining forests to supplement their livelihood (Gangwar \& Ramakrishnan, 1990; Tangjang \& Arunachalam, 2009; Singh et al., 2010; Fentahun \& Hager, 2010; Kumar et al., 2015). The Mishmi is one of the major tribes in this remote state which has been documented to harbour rich IKS on the use of various indigenous floras and tree species (Shankar \& Rawat, 2008, Namsa et al., 2009, Moyong et al., 2019, Eko et al., 2020). The majority of this community still lives in remote hamlets and depends heavily on forest products to sustain their livelihood. The rich IKS on the use of diverse floras can easily make people assume that the community domesticates the wild native groups of trees in their homegardens and other agricultural lands for day-to-day use. Many studies have documented the wild native species growing in the homegardens of the tribal population but it is equally important to study the growth status (Planted or Natural) and the regeneration potential. The objective of this study is therefore to study the native tree species growing in the homegardens of the Mishmi community, their uses, growth status and the regeneration potential so that the data can be used to analyze the actual conservation that IKS is encouraging.

\section{Material and methods}

\subsection{Study area}

The survey was extensively carried out in 19 villages from different administrative regions of the Mishmi Belt, namely Dibang Valley, Lower Dibang Valley, and Lohit Valley. Dibang Valley district is the largest district in the state with an area of $9,129 \mathrm{~km}^{2}$. It is the least populated district with a total human population of 8004 (Census of India, 2011). The district consists of only rural villages and no major town. It stands between $95.15^{\prime} \mathrm{E}$ and $96.35^{\prime} \mathrm{E}$ longitudes and 28.22' $\mathrm{N}$ and $29.27^{\prime} \mathrm{N}$ latitudes, bounded by the international boundary in the north-west, north, and east with Tibet and China, respectively. The climate is humid subtropical and temperate. Lower Dibang Valley district stands between $37.33^{\prime} \mathrm{N}$ and $24.30^{\prime} \mathrm{N}$ latitudes, and $95.15^{\prime} \mathrm{E}$ and $97.30^{\prime} \mathrm{E}$ longitudes. The climate is humid subtropical with abundant rainfall. The Lohit district lies between the latitudes $27.33^{\prime} \mathrm{N}$ and $29.22^{\prime} \mathrm{N}$ and longitude $95.15^{\prime} \mathrm{E}$ and $97.24^{\prime} \mathrm{E}$. The region is overall tropical to subtropical climate.

\subsection{Data collection and analysis}

The study was conducted for 10 months, from early November 2018 to late August 2019. A total of 243 homegardens from 19 different villages were surveyed from the three districts constituting the Mishmi belt - Dibang Valley, Lower Dibang Valley, and Lohit. The studies were carried out in each village by visiting the houses randomly during the daytime. All the villages surveyed were essentially located adjacent to the local forest area. The total homegardens visited in each village was in correspondence to the total homes in the villages, therefore, fewer homes were visited in the villages with less population (fewer homes), and more homes visited in villages with more population (more homes).

The total numbers of the trees and shrubs, their diversity, and $\mathrm{DBH}$ were recorded in the field notebook considering each homegarden as a unit. The percentage frequency ( $\mathrm{F}$ in $\%)$ of each species was measured using the given formula:

$\mathrm{F}=$ (total No. of quadrats in which species occurred/total No. of quadrats studied) $\times 100 \%$.

Based on their DBH (Diameter at Breast Height), the plants were classified into two groups. Those plants with $\mathrm{DBH}<15 \mathrm{~cm}$ were considered young, while those with $\mathrm{DBH}>15 \mathrm{~cm}$ were considered adults. The origin of the plants 


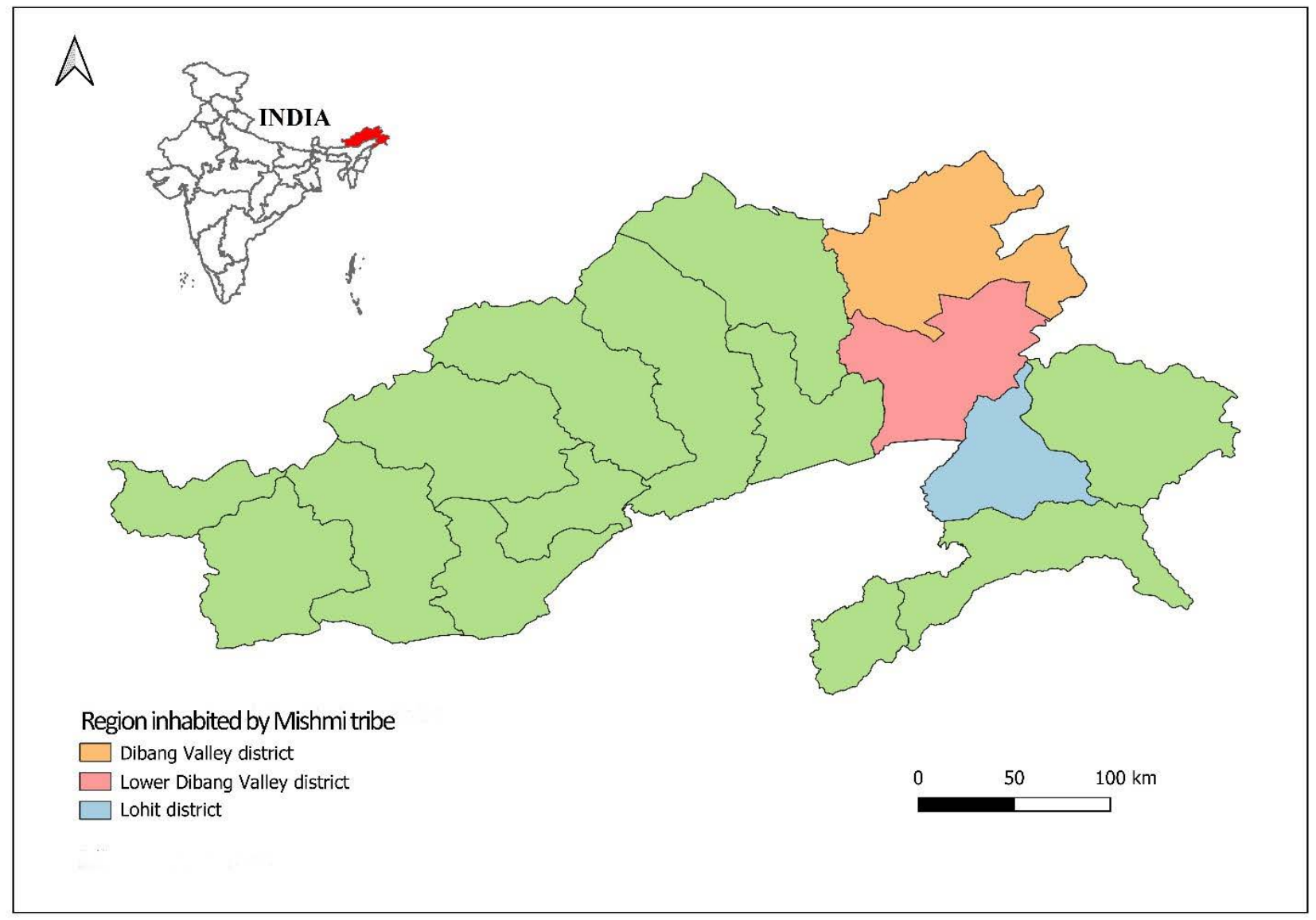

Figure 1. Map of the study area (Mishmi Belt) in Arunachal Pradesh, India

was also questioned, whether they were introduced by the owner or occur naturally. The uses and the purposes of these plants were also recorded. The collected specimens were recorded in the field notebook, dried inside an old newspaper under pressure. For identification, dried specimens were made into mounted herbarium sheets following Jain and Rao (1977) and Das (2021). The identification of the collected specimens was done consulting literature: Flora of British India (Hooker, 1998) and Flora of Assam (Kanjilal, 1934-1940) and the regional herbaria (ASSAM, ARUN). The updated names were followed using ABRS (2020) and WFO (2021). Some of the species which could not be identified have been labeled "Unknown".

\section{Results and discussion}

\subsection{Diversity}

A total of 6754 individuals belonging to 103 different species were recorded from 247 homegardens in the study area. Seventy-six species were found to be native, while the remaining 27 species were exotic (non-native). Almost all the exotic species were grown for their edible parts, commercial values, or ornamental values. The tree species grown for edible parts made up a major portion of the diversity within this exotic group as they contribute directly to household food security. The most common species (measured by percentage frequency ( $\mathrm{F}$ in \%) was Areca catech $u \mathrm{~L}$. ( $\mathrm{F}=45.3 \%)$ which was widely planted in the homegardens as well as in the farms for their fruits having high commercial value. Carica papaya $\mathrm{L}$. was equally common ( $\mathrm{F}=45.3 \%$ ), grown for its fruits. Other popular tree species included Psidium guajava L. (F=31.3\%), Mangifera indica L. (F=28.8\%), and Artocarpus heterophyllus Lam. ( $\mathrm{F}=25.1 \%)$.

Based on different $\mathrm{F}$, species were grouped into five classes (Table 1). Only three Native species had decent distribution - Bauhinia variegata $\mathrm{L}$. $(\mathrm{F}=33.3 \%)$, M. indica $(\mathrm{F}=28.8 \%)$, and A. heterophyllus $(\mathrm{F}=25.1 \%)$. B variegata is extensively used by rural populations as a fence tree for demarcating personal land boundaries. The species is preferred over others due to its high growth rate and for its easy vegetative propagation. $M$. indica and A. heterophyllus are valued for their food value. Although not as abundant as B. variegata, they, however, made their presence in most of the rural homegardens. Ninety-two percent of the native species, however, fell under the lowest 
F group implying very poor occurrence in the homegardens, most of them grew in just a single homegarden.

Although the native species constitute $74 \%$ of the total species, they, however, formed only $37 \%$ of the total tree population recorded from the study site. Depressingly, only four species (Picea sp., M. indica, B. variegata, and A. nepalensis) made up $76 \%$ of the total native tree population. The rest of the 72 native species had $\mathrm{F}<20$, barely making their presence in the homegardens with just one or two individuals. Within the exotic group too, a few groups of species maintained a dominant presence, especially those with food or commercial values such as A. catechu, C. papaya and P. guajava.

Although 76 native species were recorded from the study site, only $29 \%$ ( 22 species) of those were planted by the owners, while the rest $71 \%$ (54 species) of the species grew naturally in the homegardens (Fig. 3). Almost all of these naturally growing wild tree species occurred in just one or two homegardens. Most of the adult trees grew in the site before the land was cleared for settlement. They were left uncut mostly for providing shade and will most likely be used as firewood once the tree dies out. Similarly, the younger, non-planted native trees will also likely be weeded out in a few years from now as the owners showed no interest in tolerating those trees in the homegarden for long.

Even though 29\% (22 number) of the native species were planted by the homegarden owner themselves, only 7 of them, however, can truly be considered domesticated from the wild (by virtue of the IKS) since the rest of the 15 species cannot be considered truly wild (W) as these species today hardly constitute a member of any natural forest in the region (Fig. 3). These include already popularly domesticated species (D) such as M. indica, A. heterophyllus, Citrus maxima (Burm.) Merr., Syzygium cumini (L.) Skeels, Litchi chinensis Sonn., Livistona jenkinsiana Griff., etc. which grows natively in the region. The seven proper native tree species which have been planted are B. variegata, A. nepalensis, Zanthoxylum rhetsa (Roxb.) DC., Lagerstroemia indica L., Baccaurea ramiflora Lour., Picea sp., and Pinus sp. These seven species are preferably planted by the homegarden owners for their utility and the trees of these species can also be easily found in the nearby forest. These species, despite being used in some way, the latter four species have a very low population share, both in terms of the distribution and the regeneration potential, reflecting very low enthusiasm among homegarden owners in growing these tree species. The only native species with good distribution and regeneration potential were $B$. variegata and A. nepalensis. Both these species are used for land boundary demarcation in rural areas.
A

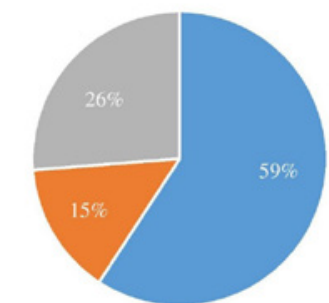

B

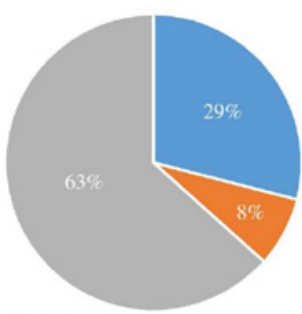

" Native wild species (W) " Native domesticated species(D) " Exotic species

Figure 2. The native (wild and domesticated) and exotic species recorded in different homegardens of Mishmi belt, Arunachal Pradesh, India: A. Percentage of species; B. Percentage of population

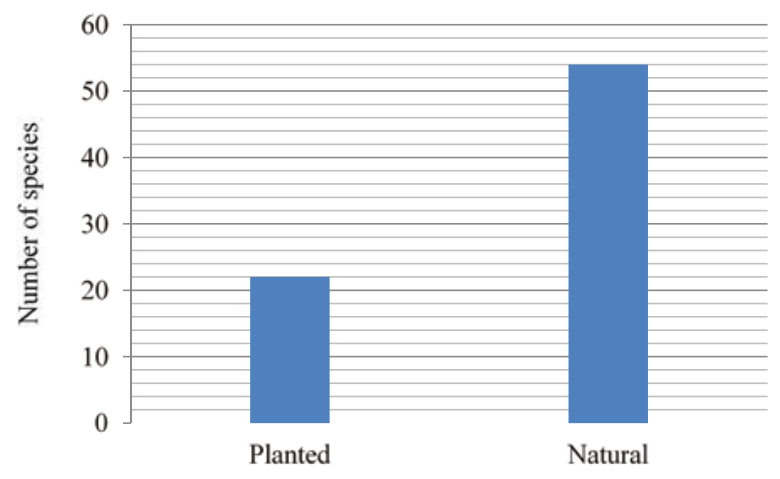

Figure 3. Chart displaying the total number of native species that are planted by homegarden owners and those that grew naturally in different homegardens of Mishmi belt, Arunachal Pradesh, India

Table 1. Distribution of woody species into different F class interval

\begin{tabular}{|l|c|c|c|c|}
\hline & \multicolumn{2}{|c|}{ Exotic species } & \multicolumn{2}{c|}{ Native species } \\
\hline $\begin{array}{c}\text { F group } \\
\text { in \% }\end{array}$ & $\begin{array}{c}\text { No. of } \\
\text { species }\end{array}$ & $\%$ & $\begin{array}{c}\text { No. of } \\
\text { species }\end{array}$ & $\%$ \\
\hline $0.00-10.0$ & 20 & 74 & 70 & 92 \\
\hline $10.1-20.0$ & 4 & 15 & 3 & 4 \\
\hline $20.1-30.0$ & 0 & 0 & 2 & 3 \\
\hline $30.1-40.0$ & 1 & 4 & 1 & 1 \\
\hline $40.1-50.0$ & 2 & 7 & 0 & 0 \\
\hline Total & 27 & 100 & 76 & 100 \\
\hline
\end{tabular}

\subsection{Regeneration status}

The exotic group of plants with a high population of the younger trees had good regeneration potential (Fig. 4) with $68 \%$ of the population (2911 individuals) constituting the younger trees. Some species within this group such as $A$. catechu, C. papaya, Malus domestica Borkh., P. guajava, Pyrus communis L., and Prunus persica (L.) Botsch contributes more to the data than the others.

Seventy-nine percent of the total native tree population (1953 individuals) belonged to adult groups, leaving only 
$21 \%$ of the total native tree population (519 individuals) as younger trees, reflecting very low regeneration potential. Most of the available young population of this small group also comes from just a few species such as $B$. variegata, $A$. nepalensis, Picea sp., $M$. indica, and $A$. indica. The regeneration potential of the two most dominant wild native species, $B$. variegata and A. nepalensis, is likely to drop down significantly in the future due to the increasing financial condition of the people in the region leading them to choose brick walls over these tree fences, especially in the homegardens, while they are still preferred for farmlands. The other 5 truly domesticated species had very poor regeneration potentials. All other groups of native trees have a very low young population implying people are not keen on planting much of these tree species. Most of these remaining species are represented by just one or two individuals in the study area and many do not have any young population in the homegardens. The most serious concern was with the group of plants in the "Non-planted" category. This group consists of 54 species, and despite consisting of the highest number of native species, has a very low population (98 individuals). Almost all the individual trees of 54 species will likely be the last to exist in the homegarden, as most of the adult trees will be used as firewood when they die, and the young trees which grew naturally will be weeded out soon. The future existence of other groups of wild native trees is also uncertain, evident by their very low occurrence in homegardens of the region and low young population, except $B$. variegata and A. nepalensis, which may be seen in future homegardens for a few more years to come. High deforestation rate in the wild and low frequency of occurrence in homegardens of the region coupled with very low regeneration potential makes this group of native tree species highly vulnerable to extinction from the local area.

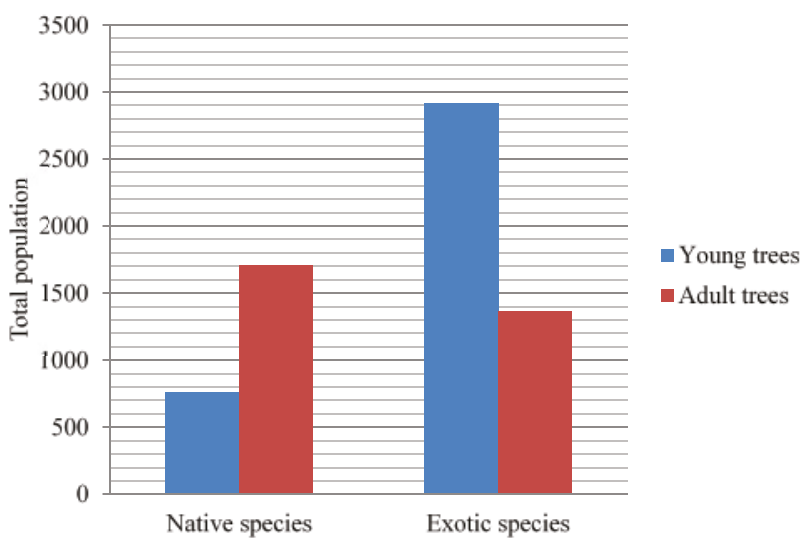

Figure 4. Age status of native and exotic trees growing in different homegardens of Mishmi belt, Arunachal Pradesh, India

\section{Conclusion}

Homegarden is, no doubt, an important site where plants can grow in the human-dominated landscape as projected by various workers, and it is true that tribal communities of the state, like any tribal communities around the globe, have huge IKS on the use of many local tree species as is evident by various studies on the NTFPs (Murtem, 2000; Sarmah, 2010; Jha, 2015; Kumar et al., 2015; Chaudhry \& Murtem, 2017). Most of the homegardens in our study sites, however, looked like any other common homegardens in other regions of northeast India, filled with exotic edible and ornamental trees. Our study showed that out of the 76 native species recorded from the region, only 7 of them can be rightfully regarded as being domesticated under IKS of the Mishmi community. The present study also shows that the mere presence of plants in the homegarden of the tribal people does not necessarily mean that they are conserved by the owners. The wild species happens to grow in those homegardens because the homegardens are mostly unmanaged or poorly managed, thereby allowing wild dispersed seeds to settle and germinate in the area. The owner may, however, be using the plant just because the plant happened to grow there. It is therefore important for any worker studying conservation in homegardens to specifically mention whether the occurring species were planted by the owner or occurred naturally. Most people might rather prefer collecting them straight from the forest as has been reported by some studies (Jha, 2015; Eko et al., 2020). This is especially of concern in the face of social changes and modernization leading to loss of IKS across each generation among the tribal communities. Since tribal people are the only people left with knowledge on the importance of local native tree species, therefore, it is important to push them into conserving those species in their homegardens and other agriculture plots before those species disappear from the local forest. Since homegarden owners do not maintain species with intention of conservation, therefore, there is a need to seriously promote native species for their utility before the traditional knowledge fades away in a successive generation.

\section{Acknowledgments}

The authors gratefully acknowledge the help and support from the Department of Botany, Rajiv Gandhi University. They are also thankful to the indigenous folk of the study area for their permission to conduct the work peacefully. 


\section{References}

ABRS, 2020, Australian Faunal Directory. Australian Biological Resources Study, Canberra. https://biodiversity.org. au/afd/home [Accesed: 12 August 2021].

Barbhuiya A.R., Sahoo U.K. \& K. Upadhyaya, 2016, Plant Diversity in the Indigenous Home Gardens in the Eastern Himalayan Region of Mizoram, Northeast India. Economic Botany 70(2): 115-131. http://dx.doi.org/10.1007/ s12231-016-9349-88

Berkes F., Colding J. \& C. Folke, 2000, Rediscovery of traditional ecological knowledge as adaptive management. Ecological Application 10: 1251-1262. https://doi.org/1 0.1890/1051-0761(2000)010[1251:ROTEKA]2.0.CO;2

Bhuyan P., Khan M.L. \& Tripathi R.S., 2003, Tree diversity and population structure in undisturbed and human-impacted stands of tropical wet evergreen forest in Arunachal Pradesh, Eastern Himalayas, India. Biodiversity and Conservation 12: 1753-1773. https://doi. org/10.1023/A:10236190177866

Census of India, 2011, Provisional population total. Directorate of census operations, Arunachal Pradesh. https:// censusindia.gov.in/2011-prov-results/prov_results_paper1_india.html.

Chaudhry P. \& Murtem G., 2017, An ethno botanical note of the plant species used by local tribes for dwelling purposes in the Eastern Himalaya of India and some forest management related pressing issues. Ecological Questions 27(3): 53-64. http://dx.doi.org/10.12775/EQ.2017.027

Das T. \& Das A.K., 2005, Inventorying plant biodiversity in homegardens: A case study in Barak Valley, Assam, North East India. Current Science 89(1): 155-163 https://www. jstor.org/stable/24110441

Das A.P., 2021, Herbarium Techniques. In: J.B. Bhandari \& Cyria Gurung (eds.), Instrumentation Mannual. Narosa Publishing House, New Delhi. p. 78-94.

Eko R., Ngomle S., Kanwat M., Kalita H. \& Moyon N.N., 2020, Eating from the wild: an insight into the indigenous wild edible plants consumed by the Digaru Mishmi tribe of Arunachal Pradesh. Indian Journal of Traditional Knowledge 19(2): 360-369. http://nopr.niscair.res.in/ handle/123456789/54349

Fentahun M. \& Hager H., 2010, Integration of indigenous wild woody perennial edible fruit bearing species in the agricultural landscapes of Amhara region Ethiopia. Agroforestry Systems 78(1): 79-95. https://doi.org/10.1007/ s10457-009-9239-5

Fraser J.A., Junqueira A.B. \& Clement C.R., 2010, Homegardens on Amazonian Dark Earth, Non-anthropogenic upland, and floodplain soils along the Brazilian middle Madeira River exhibit diverging agrobiodiversity. Eco- nomic Botany 65(1): 1-12. https://doi.org/10.1007/ s12231-010-9143-y

Gadgil M., Berkes F. \& Folke C., 1993, Indigenous knowledge for biodiversity conservation. Ambio 22: 151-56. http:// www.jstor.com/stable/4314060

Gadgil M., 1987, Diversity: cultural and biological. Trends in Ecology and Evolution 2: 369-373. http://dx.doi. org/10.1016/0169-5347(87)90138-8

Galluzi G., Eyzaguire P. \& Negri V., 2010, Homegardens: neglected hotspots of agro-biodiversity and cultural diversity. Biodiversity and Conservation 19: 3635-3654. https://doi.org/10.1007/s10531-010-9919-5

Gangwar A.K. \& Ramakrishnan P.S., 1990, Ethnobiological Notes on Some Tribes of Arunachal Pradesh, Northeastern India. Economic Botany 44(1): 94-105. https://doi. org/10.1007/BF02861071

Gupta A., Thapliyal P.K., Pal P.K. \& Joshi P.C., 2005, Impact of deforestation on Indian Monsoon - A GCM sensitivity study. J. Ind. Geophys. Union. 9(2): 97-104.

Hooker J.D., 1872-1897, The Flora of British India. Vol. 1-7. Reeve and Company, London.

Idohou R., Fandohan B., Salako V.K., Kassa B., Gbedomon R.C., Yedomonhan H., Kakaï R.L.G. \& Assogbadjo A.E., 2014, Biodiversity conservation in home gardens: traditional knowledge, use patterns and implications for management. International Journal of Biodiversity Science, Ecosystem Services \& Management 10(2): 89-100. https://doi.org/10.1080/21513732.2014.910554

Jain S.K. \& Rao R.R., 1977, A Handbook of Field and Herbarium Methods. Today \& Tomorrow's Printers and Publishers, New Delhi.

Jha K.K., 2015, Non-timber Forest Products, Their Vulnerability and Conservation in a designated UNESCO Heritage Site of Arunachal Pradesh, India. Notulae Scientia Biologicae 7(4): 444-455. https://doi.org/10.15835/ nsb749701

Kanjilal U.N., Kanjilal P.C., Das A. \& De R.N., 1934-1940, Flora of Assam, volumes 1-4. Government of Assam, Shillong.

Kanwal K.S., 2014, Non timber forest products (NTFP) as a tool for sustainable socio-economic development of community. Arunachal Times 26: 58.

Kumar N., Kumar S., Singh B., Mishra B.P., Singh B. \& Singh V., 2015, Traditional practices of utilization and conservation of non-wood forest products by Adi tribes of Arunachal Pradesh. Journal of Applied and Natural Science 7(1): 111-118. https://doi.org/10.31018/jans.v7i1.573

Kumar V. \& Tiwari A., 2017, Importance of tropical homegardens Agroforestry system. International Journal of Current Microbiology and Applied Sciences 6(9): 10021019. https://doi.org/10.20546/ijcmas.2017.609.122 
Lele N. \& Joshi P.K., 2009, Analyzing deforestation rates, spatial forest cover changes and identifying critical areas of forest cover changes in North-East India during 19721999. Environmental Monitoring and Assessment 156: 159-170. https://doi.org/10.1007/s10661-008-0472-6

Mao A.A. \& Hynniewta T.M., 2000, Floristic diversity of North East India. J. Assam Sci. Soc. 41(4): 255-266.

Moyong S., Nangkar A., Jamo L., Kalita B.C., Tsering J., Hui P.K. \& Tag H., 2019, Ethnobotany of edible fruits used by the Mishmi tribes of Lohit District in Arunachal Pradesh, India. Pleione 13(2): 317-268. https://doi:10.26679/ Pleione.13.2.2019.258-268

Murtem G., 2000, Common wild vegetables of Nyishi tribe of Arunachal Pradesh. Arunachal Forest News 18(1/2): 66-77.

Namsa N.D., Tag H., Mandal M., Kalita P. \& Das A.K., 2009, An ethnobotanical study of traditional anti-inflammatory plants used by the Lohit community of Arunachal Pradesh, India. Journal of Ethnopharmacology 125(2): 234-245. https://doi.org/10.1016/j.jep.2009.07.004

Parrotta J.A. \& Agnoletti M., 2007, Traditional forest knowledge: challenges and opportunities. Forest Ecology and Management 249: 1-4. https://doi.org/10.1016/j. foreco.2007.05.022

Paul A., Khan M.L., Arunachalam A. \& Arunachalam K., 2005, Biodiversity and conservation of Rhododendrons in Arunachal Pradesh in the Indo-Burma Biodiversity hotspot. Current science 89(4): 623-634.

Ramakrishnan P.S., 1984, Problems and prospects of conservation of plant resources eastern hill region of India, [in:] S.K. Jain, K.L. Mehra (eds.), Conservation of plant resources. Botanical Survey of India, Howrah, p. $172-180$.

Ravindranath N.H., Srivastava N., Murthy I.K., Malaviya S., Munsi M. \& Sharma N., 2012, Deforestation and forest degradation in India - implications for REDD+. Current Science 102(8): 25. https://www.jstor.org/stable/24107754
Reddy C.S., Jha C.S., Dadhwal V.K., Krishna P.H., Pasha S.V., Satish K.V., Dutta K., Saranya K.R.L., Rakesh F., Rajashekar G. \& Diwakar P.G., 2015, Quantification and monitoring of deforestation in India over eight decades (1930-2013). Biodiversity and Conservation 25: 93-116. https://doi.org/10.1007/s10531-015-1033-2

Sarmah R., 2010, Commonly used non-timber forest products (NTFPs) by the Lisu tribe in Changlang district of Arunachal Pradesh, India. SIBCOLTEJO 05: 68-77.

Shankar R. \& Rawat M.S., 2008, Medicinal plants used in traditional medicine of Lohit and Dibang valley district of Arunachal Pradesh. Indian Journal of Traditional Knowledge 7(2): 288-295.

Singh R.K., Pretty J. \& Pilgrim S., 2010, Traditional knowledge and bio-cultural diversity: learning from tribal communities for sustainable development in northeast India. Journal of Environmental Planning and Management 53(4): 511-533.

Tangjang S. \& Arunachalam A., 2009, Role of traditional homegarden systems in Northeast India. Indian Journal of Traditional Knowledge 8(1): 47-50. http://nopr.niscair. res.in/handle/123456789/2975

Tangjang S. \& Nair R.P.K., 2016, Integrated bamboo + pine homegardens: A unique agroforestry system in Ziro Valley of Arunachal Pradesh, India. International Journal of Environmental \& Agriculture Research 2(2): 25-34.

Tsering G., Nimasow G. \& Singh N.C., 2019, Impact of population growth on forest cover in Tawang District of Arunachal Pradesh, India. INT J CURR SCI. 22(10): 1-10. https://doi.org/10.5281/zenodo.4063394

WFO, 2021, World Flora Online. Published on the Internet. http://www.worldfloraonline.org [Accessed on: 12 August 202].

Yang J., Wang Y.C., Wang D. \& Guo L., 2018, Application of traditional knowledge of Hani people in biodiversity conservation. Sustainability 10(12): 4555. https://doi. org/10.3390/su10124555 